\title{
A checklist for evaluating ergonomic risk factors resulting from awkward postures of the legs, trunk and neck
}

\author{
W.M. Keyserling, M. Brouwer and B.A. Silverstein \\ Center for Ergonomics, The University of Michigan, 1205 Beal Alenue, Ann Arbor, MI 48109, USA \\ (Received February 15, 1992; accepted in revised form April 15, 1992)
}

\begin{abstract}
A one-page checklist for determining the presence of ergonomic risk factors associated with awkward postures of the lower extremities, trunk and neck was developed and cvaluated as part of a joint labor-management ergonomics intervention program. This checklist was used by plant personnel at four work sites to assess the postural requirements on 335 cyclical (i.e., work-cycle duration less than five minutes) manufacturing and warehouse jobs. In addition, results generated by the checklist were compared to the results of ergonomic analyses performed by persons with advanced training in accupational ergonomics.

Workers were observed using awkward postures for most of the jobs in the survey. Awkward postures of the lower extremities were relatively uncommon, occurring in 25 percent or less of the jobs. Awkward postures of the trunk and neck were common, occurring in more than 70 percent of the jobs. Results generated by the checklist were generally in agreement with results generated by the experienced ergonomists; however, the checklist was found to be more sensitive in identifying the presence of awkward postures.

The checklist was found to be an effective rapid-screening instrument for identifying cyclical jobs that expose workers to potentially harmful postures. However, the checklist methodology did not include sufficient documentation of work methods to identify the specific job attributes associated with these exposures. Furthermore, the checklist was not used to evaluate non-cyclical jobs (e.g., maintenance and skilled trades).
\end{abstract}

\section{Relevance to industry}

Awkward postures used in the work place may lead to worker pain and injury. The checklist presented here is a quick and sensitive screening tool for identifying jobs with exposures to postural stresses. It was effectively used by shop floor employees to analyze a variety of manufacturing and warehouse jobs.

\section{Keywords}

Ergonomic checklist; job analysis; ergonomic risk factors; awkward postures.

\section{Introduction}

Awkward postures are postures that when used repetitively or for prolonged periods result in increased risk of fatigue, pain or injury. These postures are sustained either actively by muscle contractions or passively by compressive or tensile loads on bones, muscles, tendons, ligaments, etc. (Chaffin et al., 1984). Muscle contractions require energy and produce waste products of metabolism. If the contractions are of sufficient magnitude, the blood supply to the muscles is reduced, limiting the supply of oxygen and other nutrients and allowing waste products to build up. This leads to fatigue and pain in the muscles (Astrand et al., 1986). Passive loading stresses the tissues and may result in strain. This tissue strain may lead immediately to feelings of pain or numbness or may accumulate over time and result in tissue damage or pain. Table 1 lists some 
Table 1

Adverse health effects associated with various postures.

\begin{tabular}{|c|c|c|}
\hline Posture & Adverse health effects & Reference \\
\hline Standing stationary & Compression neuropathies & Feldman et al., 1983 \\
\hline Using a fool pedal & Pain in the low back, hip and knee & Corlett et al., 1976 \\
\hline Kneeling & $\begin{array}{l}\text { Increased heart rate and oxygen consumption } \\
\text { Compression neuropathies }\end{array}$ & $\begin{array}{l}\text { Sato et al., } 1973 \\
\text { Feldman et al., } 1983\end{array}$ \\
\hline Squatting & Compression neuropathies & Feldman et al., 1983 \\
\hline Sitting w/back support & Compression neuropathies & Feldman et al., 1983 \\
\hline Sitting w/o back support & Low back pain & Grandjean et al., 1983 \\
\hline Mild flexion/trunk & $\begin{array}{l}\text { Increased heart rate and oxygen consumption } \\
\text { Back pain }\end{array}$ & $\begin{array}{l}\text { Sato et al., } 1973 \\
\text { Punnett et al., } 1991 \\
\text { Andersson, } 1981\end{array}$ \\
\hline Severe flexion/trunk & $\begin{array}{l}\text { Increased heart rate and oxygen consumption } \\
\text { Back pain }\end{array}$ & $\begin{array}{l}\text { Sato et al., } 1973 \\
\text { Punnett et al., } 1991 \\
\text { Andersson, } 1981\end{array}$ \\
\hline Twisted/bent/trunk & Back pain & $\begin{array}{l}\text { Punnett et al., } 1991 \\
\text { Andersson, } 1981\end{array}$ \\
\hline Mild flexion/neck & Neck pain and stiffness & Grandjean et al., 1983 \\
\hline Severe flexion/neck & $\begin{array}{l}\text { Pain in the neck, upper back and arms } \\
\text { Neck pain and stiffness }\end{array}$ & $\begin{array}{l}\text { Harms-Ringdahl et al., } 1986 b \\
\text { Grandjean et al., } 1983\end{array}$ \\
\hline Twist/bent/neck & $\begin{array}{l}\text { Neck and shoulder pain } \\
\text { Headache }\end{array}$ & $\begin{array}{l}\text { Tola et al., } 1988 \\
\text { Travell, } 1967\end{array}$ \\
\hline Extension/neck & Neck pain & Travell, 1967 \\
\hline
\end{tabular}

Table 2

Percentage of workers who reported pain in various areas of the body over various time periods.

\begin{tabular}{|c|c|c|c|c|c|c|c|c|c|c|}
\hline Occupation & Neck & Back & Hip & Thighs & Knee & Calf & Ankle & Feet & Time & Reference \\
\hline$\overline{\text { Butcher }}$ & 27 & 55 & 9 & & 26 & & 20 & & $3 \mathrm{mon}$ & Magnusson et al., 1987 \\
\hline Melters & 20 & 34 & & 28 & & 42 & & 30 & 1 day & Paluch, 1989 \\
\hline Molders & 10 & 26 & & 20 & & 32 & & 24 & 1 day & Paluch, 1989 \\
\hline Maintenance workers & 11 & 20 & & 22 & & 38 & & 22 & 1 day & Paluch, 1989 \\
\hline Air craft loaders & 18 & 27 & $10(t)$ & & 35 & & $6(f)$ & & 7 day & Stalhammar et al., 1986 \\
\hline Air craft loaders & 38 & 63 & $24(t)$ & & 63 & & $20(f)$ & & $1 \mathrm{yr}$ & Stalhammar et al., 1986 \\
\hline Fishermen & 19 & 52 & 13 & & 25 & & 11 & & $1 \mathrm{yr}$ & Torner et al., 1988 \\
\hline Slaughterhouse workers & $49(5)$ & 42 & & & & & & & $1 \mathrm{yr}$ & Viikari-Juntura, 1983 \\
\hline Electronics assembly & 64 & 11 & 10 & 12 & $4(a)$ & & & & & Westgaard et al., 1984 \\
\hline Cable makers & 31 & 39 & 4 & 4 & $0(a)$ & & & & & Westgaard et al., 1984 \\
\hline Machine operators $(45-49)$ & 86 & & & & & & & & & Tola et al., 1988 \\
\hline Carpenters $(45-49)$ & 76 & & & & & & & & & Tola et al., 1988 \\
\hline Office workers $(45-49)$ & 62 & & & & & & & & & Tola et al., 1988 \\
\hline Strawberry pickers & 14 & 60 & $10(1)$ & & & & & & & Maeda et al., 1980 \\
\hline Eggplant pickers & 11 & 43 & $40(1)$ & & & & & & & Maeda et al., 1980 \\
\hline
\end{tabular}

Note: (a) includes ankles; (f) includes feet; (I) includes legs; (s) includes shoulder; (t) includes thigh. Some values estimated from graphs. 
of the adverse health effects associated with awkward lower extremity, trunk and neck postures.

Pain is often associated with awkward postures (see table 1). Table 2 summarizes the percentage of workers in different industries who have experienced pain in the lower extremity, trunk or neck. These data are taken from studies that investigated the relationship between working posture and discomfort, pain and/or injury. The data in table 2 indicate that low back pain is a common problem. Furthermore, pain is experienced in the neck, knee, calf and feet by about one-third of workers in some industries.

Many methods for measuring posture are available. Atha (1984) reviewed posture measurement for sports applications including: photographic methods, goniometers, accelerometers and opto-electronic co-ordinate analyzers. Many of these methods are impractical for use on the shop floor because of cost, complexity, calibration difficulties and the invasiveness of the technique. Other methods for describing posture include direct observation and manual recording using forms (Karhu et al., 1977; Corlett et al., 1979; Priel, 1974) and computer-aided methods (Keyserling, 1986; Kilbom et al., 1986b). Limitations of these methods for use as shop-floor screening tools include: cost, the level of training required, the application time and the need for additional analysis using special equipment to determine the exposure level. In spite of these limitations, these methods and others have been used to describe workers' posture.

The study reported below involved three steps. The first step was to design and develop a screening tool that could be used quickly, easily, and accurately by shop floor workers with a minimum of training or equipment. The screening tool developed was a checklist, as has recently been suggested by OSHA. Due to the significant ergonomic problems in the meatpacking industry, the Occupational Safety and Health Administration (OSHA) issued a document titled "Ergonomic Program Management Guidelines for Meatpacking Plants" (OSHA, 1990). This publication states:

\footnotetext{
"The goal of any safety and health program is to prevent injuries and illnesses by removing their causes. For ergonomics, this goal is to eliminate or materially reduce worker
}

exposure to ergonomic hazards that lead to cumulative trauma disorders and related injuries and illnesses."

The OSHA guidelines recommend that an effective control program include a systematic analysis of the work site to recognize, identify and correct ergonomic hazards. The guidelines further recommend the use of a checklist to identify jobs with ergonomic hazards, including awkward postures. The second step was to use the checklist to analyze a variety of industrial tasks. The final step was to compare the checklist results with the results of experienced ergonomists to confirm that shop floor workers with one week of ergonomic training could correctly identify ergonomic stresses resulting from awkward postures.

The following sections describe the development, implementation and evaluation of a checklist to evaluate ergonomic risk factors associated with awkward postures of the neck, trunk and lower extremities. A similar checklist designed to screen for upper extremity risk factors (Keyserling et al., in press) was also developed as part of this study.

\section{Methods}

\section{Objectives and environment}

The checklist described below was developed in conjunction with a 42-month longitudinal study to evaluate the effectiveness of a joint unionmanagement program in reducing ergonomic injuries and disorders in a large automotive corporation. This study was performed at four work sites (an engine plant, a metal stamping plant and two parts distribution warehouses), all located in the same metropolitan area.

The checklist was designed to be a structured ergonomic job evaluation tool for use on the plant floor by representatives of management and labor. All users participated in a one-week training program that included lectures on ergonomic fundamentals as well as practical exercises on job analysis and use of the checklist. Other than this one-week course, most users had no additional formal training in ergonomics.

The posture checklist was designed to function 
as a rapid, sensitive screening tool to identify jobs with potentially harmful exposures to ergonomic stress. The speed-of-use critcrion required that it should be completed in about five minutes. The sensitivity criterion required that the checklist identify the presence of all potentially harmful postural stresses. As a screening tool, the checklist was designed to be biased, more likely to classify an "acceptable" job as a "problem" job (a false positive) than to classify a "problem" job as "acceptable" (a false negative). The checklist was not designed to be a diagnostic tool. Therefore, it did not provide sufficient information to identify specific work attributes responsible for excessive stress or provide insights as to how the job could be redesigned to reduce ergonomic stress. (Additional analyses using open-ended methods were required to accomplish these objectives. These follow-up analyses would also identify situations where the checklist produced a false positive.)

\section{Checklist fundamentals}

A complete version of the Posturc Checklist and the associated explanatory notes are presented in the Appendix. The checklist consisted of a series of objective questions with multiple choice responses. Each question was designed to evaluate the presence and duration of exposure to awkward postures. The following categories were used to estimate the duration of exposure:

Never: The job involved no exposure to the particular posture.

Sometimes: The posture was required to perform the job, however the total duration of the posture was less than one-third of the work cycle or work day.

Greater than one-third: The posture was required to perform the job and the total duration was greater than one-third of the work cycle or work day.

The response to cach question resulted in a stress rating (see checklist in the Appendix) that utilized a three-level qualitative scale:

Zero: Using the posture for the indicated duration presented insignificant risk of injury or illness.

Check: Moderate exposure to postural stress was present, indicating a potential risk of injury to some workers.
Star: Substantial exposure to postural stress was present, indicating significant risk of injury.

The most common mapping between the duration of awkward posture and the associated stress rating was:

$$
\begin{aligned}
& \text { Duration- - . - Stress rating } \\
& \text { Never- .... Z Zero } \\
& \text { Sometimes- - . - - Check } \\
& \text { Greater than one-third - . - - Star }
\end{aligned}
$$

However, there were several important deviations from this general rulc, as discussed in the next section.

Once the checklist was completed, the total number of checks and stars were summed, producing an overall score of posture stresses. (Note: Because the rating system was qualitative (i.e., "star" responses on different questions did not necessarily indicate equal levels of absolute risk), checklist users were instructed to interpret the overall score with caution. Since the checklist was designed as a screening tool to identify jobs which should undergo follow-up analyses, any job receiving one or more "Stars" was considered to have high priority for additional investigation and analysis.)

\section{Development of checklist questions}

The chccklist was structured to identify three general categories of exposure to awkward postures: Lower Extremities, Trunk and Neck. Refer to the appendix for details regarding posture and activity definitions, duration categories and associated stress ratings.

\section{Lower extremity postures and activities}

Work situations that required cmployees to stand stationary with the feet bearing the body's weight for a prolonged period of time were identified in Qucstion 1. Standing stationary can be a risk factor for pain in the low back, hips, legs, knees, ankles and feet (Buckle et al., 1986; Ryan, 1989). Standing has also been associated with compression of the posterior tibial nerve at the ankle (Aguayo, 1975), increased venous pressure in the legs and varicose veins (Coffman, 1975). Because these symptoms are the result of prolonged exposure, "Never" and "Sometimes" were 
assigned ratings of "Zero", while " $>1 / 3$ cycle" was assigned a "Check".

Worker use of a foot pedal while standing was the focus of Question 2. Standing use of a foot pedal has been found to be a risk factor for pain at the knee, hip and/or low back (Corlett et al., 1978).

Lying on the back or side, addressed in Question 3, was included in the checklist for several reasons. First, lying down and getting up can place a high metabolic demand on the operator, especially if the task is repetitive. Second, lying down, when associated with maintenance procedures, often involves confined spaces, constrained postures and/or infrequently performed (and therefore, unaccustomed) tasks. The resulting stresses are often cited as risk factors for pain in various parts of the body. Third, lying down often results in inadequate body support, stressing the muscles used to support the head, arms or legs, or causing mechanical contact stress with the workstation.

The duration of kneeling was evaluated by Question 4. Kneeling was defined as one or both knees touching the ground. Kneeling has been: (1) rated a stressful posture by foundry workers and ergonomic experts (Karhu et al., 1977); (2) reported to increase the risk of pain or injury at the knee (Tanaka et al., 1982); and (3) reported to cause compression of the peroneal nerve (Spaans, 1970).

Squatting (an included angle between the thigh and calf of less than 150 degrees) was identified in Question 5. Squatting has been: (1) rated as a stressful posture by foundry workers and ergonomic experts (Karhu et al., 1977); (2) reported to cause compression of the common peroneal nerve (Koller et al., 1980; Sandhu et al., 1976); and (3) reported to cause the compression of the posterior tibial nerve (Joubert, 1972). Deep squatting has been associated with compression of the plantar nerves (Aguayo, 1975) and has been shown to increase bone-on-bone and compression forces in the knee by a biomechanical model (Ariel, 1974).

\section{Trunk posture}

Sitting during the work day was evaluated in Questions 6 and 7. Sitting with a back support was the focus of Question 6. Sitting has been shown to be a risk factor in the development of low back pain (Magora, 1972); reported to cause compression of the sciatic nerve (Deverell et al., 1968; Aguayo, 1975), and foot swelling (Winkel et al., 1988). Sitting without a back support was addressed in Question 7. Sitting in a seat equipped with lumbar support has been shown to reduce the stress on the lumbar spine in biomechanical studies (Andersson et al., 1974a; Andersson et al., 1974b). Because sitting with back support reduces the stress on the back, Never and Sometimes sitting were rated a Zero on the checklist, while sitting for more than $1 / 3$ of the day was rated a Check.

Non-neutral trunk postures were examined using Questions 8 through 11. Postures such as flexion, twisting, or lateral bending have been associated with increased risk of back pain (Punnett et al., 1991). Other risks include: increased discomfort in the lower extremities and decreased time a posture can be maintained as the angle of flexion increases (Boussenna et al., 1982); and increased biomechanical loads (Andersson et al., 1977; Nachemson, 1966). Because severe forward bending (more than 45 degrees forward flexion) is so stressful, any exposure to this posture received a "Star" rating. Extension of the trunk (Question 10) was included to complete the trunk posture description.

\section{Neck posture}

Mild neck flexion of between 20 degrees and 45 degrees was the focus of Question 12. Neck flexion has been shown to be related to neck pain as a function of the angle of flexion, the time spent with the neck flexed and the number of flexions per hour (Hunting et al., 1980; Kilbom et al., 1986a; Kilbom et al., 1987). Since these symptoms develop from prolonged exposure, "Never" and "Sometimes" were assigned "Zero" ratings; while "> $1 / 3$ cycle" was assigned a "Check" rating.

Severe neck flexion of more than 45 degrees was analyzed using Question 13. This posture has been associated with the following: 360 percent increase in the moment about the C7-T1 joint, which may be damaging to the passive tissue supporting the load (Harms-Ringdahl et al., 1986a); and increased fatigue rates (Chaffin, 1973). Finally, maximal forward neck flexion can 
cause pain or discomfort after only 15 minutes of exposure (Harms-Ringdahl et al., 1986b).

Neck extension (backward bending) of more than 20 degrees, which is reported to cause neck pain (VanWely, 1970), was evaluated using Question 14.

Neck twisting and/or lateral bending of more than 20 degrees was monitored using Question 15. These postures have been shown to result in increased occurrence of neck and shoulder symptoms (Tola et al., 1988).

Using the checklist: A survey of awkward posture in four plants

The checklist was used to evaluate ergonomic stresses resulting from awkward postures on 335 jobs in selected departments of four different plants. These analyses were performed by plant employees following a one-week ergonomics training program that included instruction and practice in checklist use. Because the checklists were used prior to the implementation of any job improvements to reduce exposures to ergonomic stresses, the resulting data described the status of posture risk factors at the outset of the joint labor-management ergonomics program.

Work activities and specific job requirements varied considerably among and within the plants. Job requirements in the engine plant $(n=67$ jobs) included: repetitive manual handling of moderately heavy parts (e.g., $25 \mathrm{~kg}$. engine heads) when loading and unloading automated machining, surface finishing and assembly equipment; visual and tactile inspections of in-process parts; and manual assembly operations. In the metal stamping plant ( $n=133$ jobs) job requirements included: manual handling of blanks and/or previously stamped parts when loading or unloading presses and semi-automated welding equipment; using operating controls such as "two-handed safety buttons" to activate power presses and welding machines; and stacking moderately-heavy finished components to containers for shipping. At the two warchouses $(n=57$ jobs in Warehouse $\mathrm{A}, n=78$ jobs in Warehouse $\mathrm{B}$ ), job requirements included: manually depalletizing bulk incoming shipments of a variety of light and moderately-heavy automotive replacement parts (catalytic converters, transmission components, brake components etc.); visual and tactile inspections of replacement parts; manual and semi-automated packaging of single parts; and manual handling of packaged parts for temporary storage or shipment.

Statistics summarizing responses to checklist questions are presented in the Results section for each participating plant and for the total study. Responses that gave the same stress ratings for multiple duration categories were pooled. Thus "Zero" stress responses in Questions 1, 6 and 12 were pooled into a duration category of " $<1 / 3$ cycle" (see the checklist in the Appendix and tables 5,6 and 7). Also, the "Star" stress ratings in Question 9 were pooled into a duration category of "Any". In addition, a Chi-square test of independence (Gibbons, 1971) was used to evaluate the significance of plant effects.

\section{Evaluating the checklist as a screening tool}

The checklist presented in the Appendix was designed to function as a rapid screening tool for use by persons with relatively little training and experience in ergonomics to identify jobs with potentially harmful awkward postures. In order to assess the effectiveness of the checklist in accomplishing these objectives, responses to checklist questions covering trunk and neck postures were compared to the results of "expert" computer-aided video analyses performed by university personnel (research engineers and advanced graduate students) with extensive experience in ergonomic job analysis techniques. The comparison was made using a subset of 51 of the 335 jobs. All 51 of these jobs were analyzed for the trunk postures. However, of the 51 jobs only 24 were analyzed for neck posture. The remaining 27 jobs were not analyzed because the workers' heads were not captured on video tape for the whole work cyclc. There were two reasons for the reduced sample size for neck posture comparisons. First, the worker's face was not included in video tape, where possible, to maintain the anonymity of subjects. Second, the head was blocked from view by parts of the workstation or the worker's body. For a complete description of the "expert" analysis procedures and methods see Keyserling et al. (1991).

The cxpert analysis of trunk and neck posture was performed using a quantitative computer- 
aided procedure (Keyserling, 1990) that measured the actual time and the percentage of the work cycle during which the trunk and neck were in various pre-defined postures. The definitions of trunk and neck postures used by the experts and the checklist were the same. These postures are depicted in figure 1.

To facilitate comparison with checklist results, percentage of cycle times obtained in the expert analysis were transformed into one of the following duration categories:
None: less than 1 percent of the cycle time was spent in the posture of interest;

Some: 1 to 33 percent of the cycle time was spent in the posture of interest;

More than one-third: more than 33 percent of the cycle time was spent in the posture of interest.

As described above, the responses to several checklist questions were pooled based on the stress ratings. To match the pooled checklist categories the expert results for Questions 9 and 12

Table 3

Results of a survey of 335 automotive jobs using a checklist to identify lower extremity postures and activities.

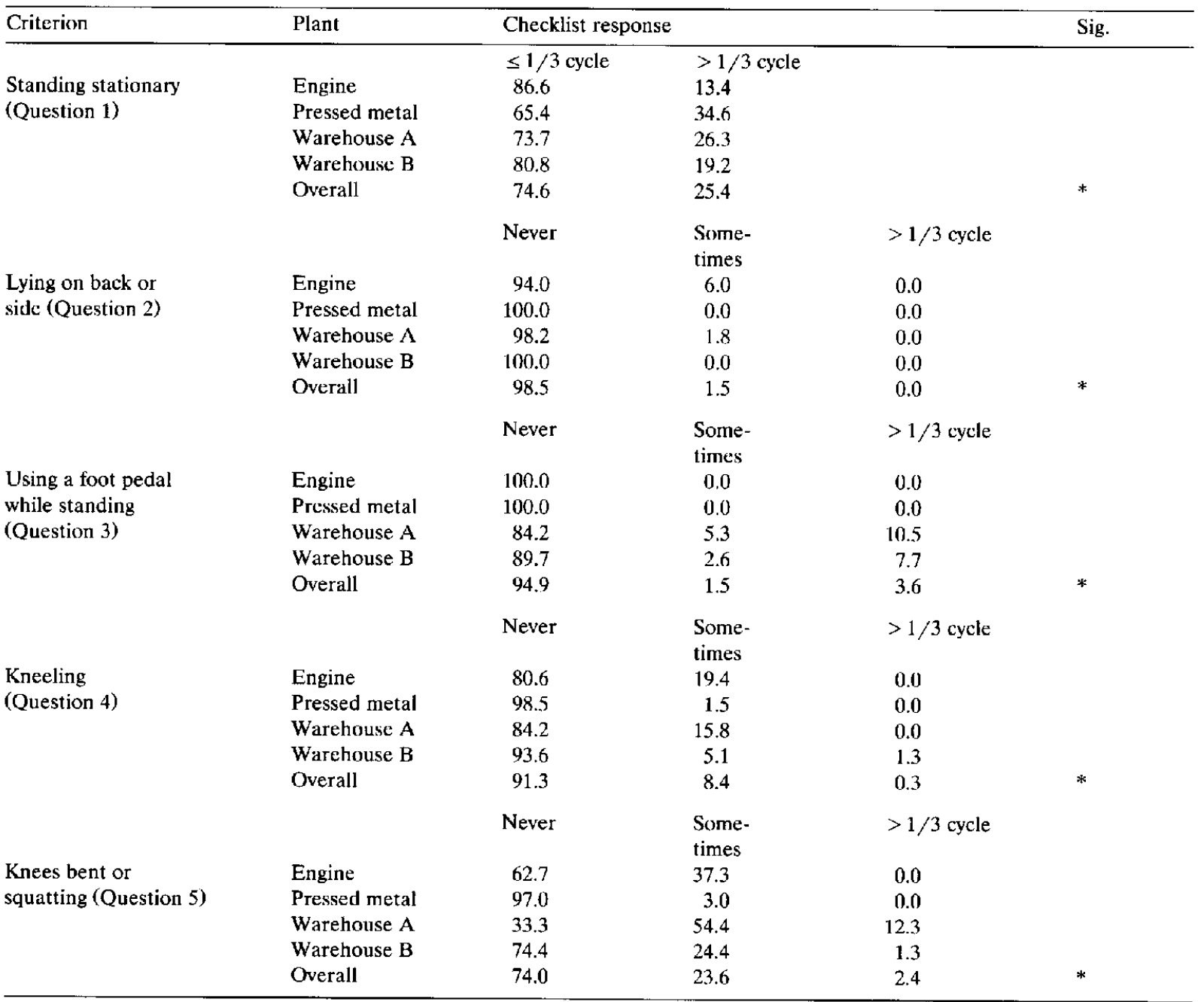

\footnotetext{
${ }^{*} p<0.01$ using Chi-square test of independence.
}

(Engine $=67$ jobs, Pressed metal $=133$ jobs, Warehouse $A=57$ jobs, Warehouse $B=78$ jobs) 


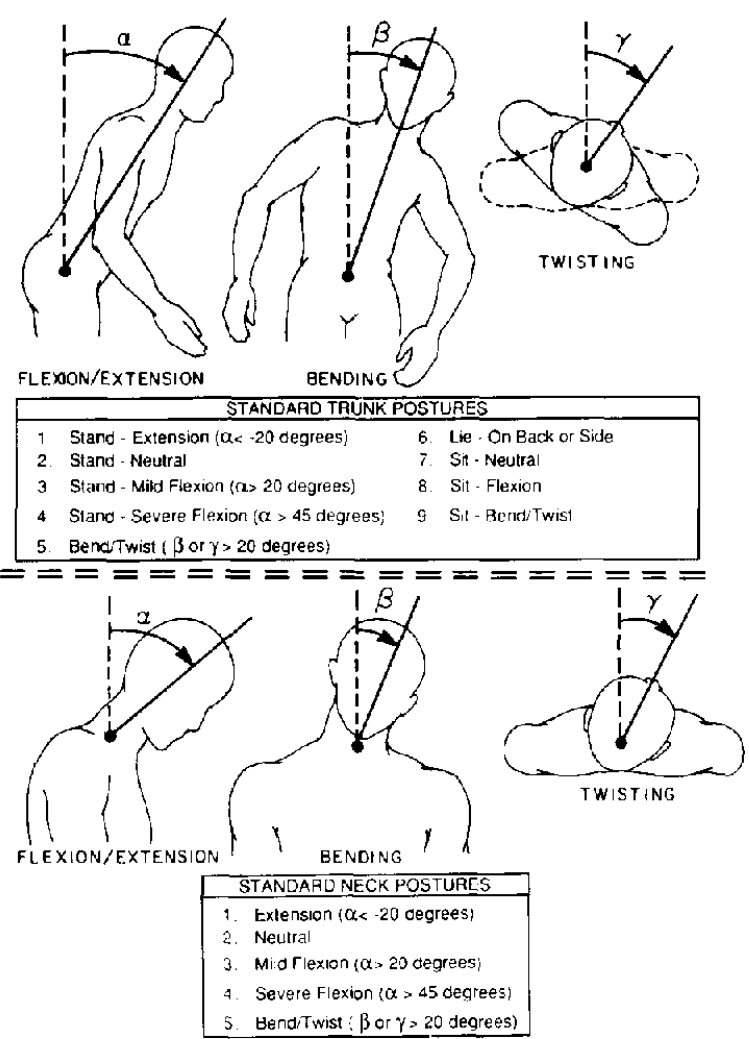

Fig. 1. Standard trunk and neck posture used in the expert analysis (Keyserling, 1990).

were combined into similar categories. For Question 9, the categories were "None" and "Any" ( $>1$ percent of the cycle time). For Question 12, the categories were $<33$ percent and $>33$ percent.

The checklist results were compared to the expert analysis using two-way $3 \times 3$ or $2 \times 2$ contingency tables:

\begin{tabular}{llll}
\hline \multirow{2}{*}{$\begin{array}{l}\text { Expert } \\
\text { classification }\end{array}$} & \multicolumn{3}{l}{ Checklist classification } \\
\cline { 2 - 4 } & Never & Sometimes & $>1 / 3$ Cycle \\
\hline None & $=$ & + & + \\
Some & - & $=$ & + \\
$>33 \%$ Cycle & - & - & $=$ \\
\hline
\end{tabular}

Where the checklist and the expert were in agreement, the table entry would be on the main diagonal (an " $=$ " in the above example). Where the checklist over-estimated ergonomic stress relative to the expert analysis, the table entry was in the upper right corner (a "+ " in the above example). Similarly, if the checklist underestimated crgonomic stress, the table entry was in the lower left corner (a " - " in the example).

\section{Results}

Survey of postural stresses based on checklist responses

\section{Lower extremity postures and activities}

Lower extremity postures and activities stresses cvaluated in checklist Questions 1-5 are summar-

Table 4

Results of a survey of 335 automotive jobs using a checklist to identify postural risk factors associated with sitting.

\begin{tabular}{|c|c|c|c|c|c|}
\hline Criterion & Plant & Checklist res & & & Sig. \\
\hline & & $\leq 1 / 3$ cycle & $>1 / 3$ cycle & & \\
\hline Sitting with back & Engine & 97.0 & 3.0 & & \\
\hline support (Question 6) & Pressed metal & 98.5 & 1.5 & & \\
\hline & Warehouse A & 75.4 & 24.6 & & \\
\hline & Warehouse B & 87.2 & 12.8 & & \\
\hline & Overall & 91.6 & 8.4 & & $*$ \\
\hline & & Never & $\begin{array}{l}\text { Some- } \\
\text { limes }\end{array}$ & $>1 / 3$ cycle & \\
\hline Sitting without back & Engine & 92.5 & 6.0 & 1.5 & \\
\hline support (Question 7) & Pressed metal & 99.2 & 0.8 & 0.0 & \\
\hline & Warehouse A & 63.2 & 31.6 & 5.3 & \\
\hline & Warehouse B & 87.2 & 10.3 & 2.6 & \\
\hline & Overall & 89.0 & 9.3 & 1.8 & $*$ \\
\hline
\end{tabular}

\footnotetext{
${ }^{*} p<0.01$ using Chi-square test of independence
}

(Engine $=67$ jobs, Pressed metal $=133$ jobs, Warehouse $A=57$ jobs, Warehouse $B=78$ jobs) 
ized in table 3. Stationary standing (Q1) for more than one-third of the cycle time was required on about 25 percent of the jobs. It was most prevalent in the pressed metal plant where workers operated presses and semi-automated welders. In the other plants, stationary posture was less common since workers had to carry parts between conveyors and pallets or bins.

Lying on the back or side (Q2) was quite rare, observed on only 1.5 percent of the jobs and usually associated with the setup or servicing of equipment.

Using a foot pedal while standing (Q3) was required on 5 percent of the jobs. This risk factor was observed in the warehouses where foot ped- als were used for operating packaging machines and various types of industrial trucks.

Kneeling (Q4) was present in 9 percent of the jobs. In the engine plant, it was associated with maintenance workers setting up machines and with stock handlers working at or near floor level during palletizing/depalletizing. In warehouse A, kneeling occurred when assembling and filling large wooden crates with parts for shipping.

Squatting (Q5) was recorded in 26 percent of the jobs. In the engine plant, it was associated with handling parts on the lower levels of pallets. In both warehouses, squatting resulted from working at the lower levels of pallets and bins and when retrieving parts from a rack storage

Table 5

Results of a survey of 335 automotive jobs using a checklist to identify postural risk factors associated with trunk posture.

\begin{tabular}{|c|c|c|c|c|c|}
\hline \multirow[t]{2}{*}{ Criterion } & \multirow[t]{2}{*}{ Plant } & \multicolumn{3}{|c|}{ Checklist response } & \multirow[t]{2}{*}{ Sig } \\
\hline & & Never & $\begin{array}{l}\text { Some- } \\
\text { times }\end{array}$ & $>1 / 3$ cycle & \\
\hline \multirow{6}{*}{$\begin{array}{l}\text { Mild forward trunk } \\
\text { bending }\left(>20^{\circ}\right) \\
\text { (Question } 8 \text { ) }\end{array}$} & Engine & 7.5 & 67.2 & 25.4 & \\
\hline & Pressed metal & 12.0 & 82.7 & 5.3 & \\
\hline & Warehouse A & 12.3 & 54.4 & 33.3 & \\
\hline & Warehouse B & 10.3 & 64.1 & 25.6 & \\
\hline & Overall & 10.7 & 70.4 & 18.8 & $* *$ \\
\hline & & Never & Any & & \\
\hline \multirow{6}{*}{$\begin{array}{l}\text { Severe forward } \\
\text { trunk bending }\left(>45^{\circ}\right) \\
\text { (Question } 9 \text { ) }\end{array}$} & Engine & 20.9 & 79.1 & & \\
\hline & Pressed metal & 72.2 & 27.8 & & \\
\hline & Warehouse A & 40.4 & 59.6 & & \\
\hline & Warehouse B & 37.2 & 62.8 & & \\
\hline & Overall & 48.4 & 51.6 & & $* *$ \\
\hline & & Never & $\begin{array}{l}\text { Some- } \\
\text { times }\end{array}$ & $>1 / 3$ cycle & \\
\hline \multirow{6}{*}{$\begin{array}{l}\text { Backward trunk } \\
\text { bending }\left(>20^{\circ}\right) \\
\text { (Question } 10)\end{array}$} & Engine & 94.0 & 6.0 & 0.0 & \\
\hline & Pressed metal & 97.0 & 3.0 & 0.0 & \\
\hline & Warehouse A & 84.2 & 14.0 & 1.8 & \\
\hline & Warehouse B & 97.4 & 2.6 & 0.0 & \\
\hline & Overall & 94.3 & 5.4 & 0.3 & $*$ \\
\hline & & Never & $\begin{array}{l}\text { Some- } \\
\text { times }\end{array}$ & $>1 / 3$ cycle & \\
\hline \multirow{5}{*}{$\begin{array}{l}\text { Twisting or lateral } \\
\text { trunk bending }\left(>20^{\circ}\right) \\
\text { (Question } 11)\end{array}$} & Engine & 17.9 & 68.7 & 13.4 & \\
\hline & Pressed metal & 22.6 & 74.4 & 3.0 & \\
\hline & Warehouse A & 10.5 & 73.7 & 15.8 & \\
\hline & Warehouse B & 20.5 & 59.0 & 20.5 & \\
\hline & Overall & 19.1 & 69.6 & 11.3 & $* *$ \\
\hline
\end{tabular}

$* p<0.05$ using Chi-square test of independence.

${ }^{* *} p<0.01$ using Chi-square test of independence.

(Engine $=67$ jobs, Pressed metal $=133$ jobs, Warehouse $A=57$ jobs, Warehouse $B=78$ jobs) 
system. Less kneeling and squatting were required in the pressed metal plant because parts were supplied to the workers on conveyors or in parts bins that were positioned between knuckle and elbow height.

\section{Trunk postures - sitting}

Survey results for sitting (Q6 and 7) are presented in table 4. Eight percent of workers sat with back support for more than one third of the day, while 11 percent sat without back support. These low figures are attributable to the nature of the work (materials handling and machine operation) and the workstation layout (i.e., it is uncommon to find seated jobs in "heavy" manufacturing or warehouse operations). Sitting was most common in warehouses $\mathrm{A}$ and $\mathrm{B}$, where workers sat while repacking small parts from bulk storage into individual containers. In contrast, sitting at the other facilities was extremely rare (with few exceptions, e.g. inspection tasks) because of the dimensions of the workstation and material handling requirements.

\section{Trunk postures - standing}

Trunk posture results are presented in table 5 . Mild flexion (Q8) occurred on 89 percent of the jobs, with 19 percent of the jobs requiring this posture for more than one-third of the cycle time. In the pressed metal plant, however, only 5 percent of the jobs had more than one-third of cycle spent in mild flexion. This was due to the extensive use of conveyors and parts bins positioned between knuckle and elbow height.

Severe trunk flexion (greater than 45 degrees) for any duration was required on 52 percent of

Table 6

Results of a survey of 335 automotive jobs using a checklist to identify postural risk factors associated with neck posture.

\begin{tabular}{|c|c|c|c|c|c|}
\hline Criterion & Plant & Checklist res & & & Sig. \\
\hline $\begin{array}{l}\text { Mild forward neck } \\
\text { flexion }\left(>20^{\circ}\right) \\
\text { (Question 12) }\end{array}$ & $\begin{array}{l}\text { Engine } \\
\text { Pressed metal } \\
\text { Warehouse A } \\
\text { Warehouse B } \\
\text { Overall }\end{array}$ & $\begin{array}{l}\leq 1 / 3 \text { cycle } \\
70.1 \\
82.0 \\
45.6 \\
67.9 \\
70.1\end{array}$ & $\begin{array}{l}>1 / 3 \text { cycle } \\
29.9 \\
18.0 \\
54.4 \\
32.1 \\
29.9\end{array}$ & & * \\
\hline $\begin{array}{l}\text { Severe forward neck } \\
\text { flexion }\left(>45^{\circ}\right) \\
\text { (Question } 13 \text { ) }\end{array}$ & $\begin{array}{l}\text { Engine } \\
\text { Pressed metal } \\
\text { Warehouse A } \\
\text { Warehouse B } \\
\text { Overall }\end{array}$ & $\begin{array}{l}\text { Never } \\
29.9 \\
71.4 \\
52.6 \\
65.4 \\
58.5\end{array}$ & $\begin{array}{l}\text { Some- } \\
\text { times } \\
64.2 \\
20.3 \\
40.4 \\
25.6 \\
33.7\end{array}$ & $\begin{array}{l}>1 / 3 \text { cycle } \\
\\
6.0 \\
8.3 \\
7.0 \\
9.0 \\
7.8\end{array}$ & * \\
\hline $\begin{array}{l}\text { Backward neck } \\
\text { bending }\left(>20^{\circ}\right) \\
\text { (Question } 14 \text { ) }\end{array}$ & $\begin{array}{l}\text { Engine } \\
\text { Pressed metal } \\
\text { Warehouse A } \\
\text { Warehouse B } \\
\text { Overall }\end{array}$ & $\begin{array}{l}\text { Never } \\
92.5 \\
98.5 \\
45.6 \\
84.6 \\
85.7\end{array}$ & $\begin{array}{l}\text { Some- } \\
\text { times } \\
7.5 \\
1.5 \\
49.1 \\
11.5 \\
13.1\end{array}$ & $\begin{array}{l}>1 / 3 \text { cycle } \\
0.0 \\
0.0 \\
5.3 \\
3.8 \\
1.8\end{array}$ & * \\
\hline $\begin{array}{l}\text { Twisting or lateral } \\
\text { neck bending }\left(>20^{\circ}\right) \\
\text { (Question 1.5) }\end{array}$ & $\begin{array}{l}\text { Engine } \\
\text { Pressed metal } \\
\text { Warehouse A } \\
\text { Warehouse B } \\
\text { Overall }\end{array}$ & $\begin{array}{l}\text { Never } \\
17.9 \\
30.8 \\
5.3 \\
38.5 \\
25.7\end{array}$ & $\begin{array}{l}\text { Some- } \\
\text { times } \\
65.7 \\
63.2 \\
70.2 \\
51.3 \\
62.1\end{array}$ & $\begin{array}{l}>1 / 3 \text { cycle } \\
16.4 \\
6.0 \\
24.6 \\
10.3 \\
12.2\end{array}$ & * \\
\hline
\end{tabular}

* $p<0.01$ using Chi-square test of independence.

(Engine $=67$ jobs, Pressed metal $=133$ jobs, Warehouse $A=57$ jobs, Warehouse $B=78$ jobs) 
the jobs. In the engine plant, this posture was used in 79 percent of the jobs, while in the pressed metal plant exposure occurred in only about 28 percent of the jobs. The engine plant exposure was the result of reaching across 5foot-wide pallets and/or reaching below knee level to get parts from the lower level(s) of pallets placed on the floor.

The least prevalent trunk risk factor was extension, which was present in only 6 percent of the jobs (Q10). This posture was most common at warehouse A (about 16 percent of jobs) and was associated with industrial truck drivers looking up while getting or placing loads.

Twisting or lateral bending of the trunk was observed in 81 percent of the jobs (Q11). Fewer workers in the pressed metal plant used prolonged twisted/bent postures because of the effective layout of conveyors and parts bins.

\section{Neck posture}

Neck posture survey results are presented in table 6. Mild neck flexion of 20 degrees to 45 degrees (Q12) for more than one-third of the cycle time was found in 30 percent of the jobs, with a maximum of 54 percent on the jobs in warehouse $A$. In this plant, neck flexion occurred on jobs where bulk parts were packaged into individual containers on low benches and machines.

Severe neck flexion of more than 45 degrees (Q12) was observed in 41 percent of the jobs. The range was from 29 percent of the jobs in pressed metal to 70 percent of the jobs in the engine plant. Neck flexion was required in the engine plant when working at the lower levels of pallets and in assembly and inspection tasks located at or below waist height.

Neck extension was relatively uncommon, present in only 14 percent of the jobs. In warehouse A, however, it was observed in 54 percent of the jobs, due to the number of jobs which required looking up (i.e. industrial truck driver).

Twisting or lateral bending of the neck was required in 74 percent of the jobs. Warehouse $A$ stands out again with 95 percent of the jobs requiring some twisting or lateral bending and 24 percent of the jobs requiring prolonged twisting/ bending. The twisting or lateral bending was required in the two main tasks at warehouse A: (1)
Table 7

Checklist vs. expert analysis of postural stresses associated with mild trunk flexion $\left(20^{\circ}-45^{\circ}\right)$.

\begin{tabular}{llcc}
\hline Experts & \multicolumn{2}{l}{ Checklist result } \\
\cline { 2 - 3 } results & Never & Sometimes & $>1 / 3$ cycle \\
\hline $\begin{array}{l}\text { None } \\
\quad(<1 \% \text { cycle })\end{array}$ & 0 & 7 & 3 \\
Some & & & \\
$\quad(1-33 \%$ cycle $)$ & 2 & 24 & 15 \\
$>33 \%$ cycle & 0 & 0 & 0
\end{tabular}

Perfect agreement (main diagonal) $=24$ jobs, 47 percent of jobs in sample

Checklist rating $>$ Expert rating $=25$ jobs, 49 percent of jobs in sample

Checklist rating $<$ Expert rating $=2$ jobs, 4 percent of jobs in sample

Table 8

Checklist vs. expert analysis of postural stresses associated with severe trunk flexion (more than $45^{\circ}$ ).

\begin{tabular}{lll}
\hline $\begin{array}{l}\text { Expert } \\
\text { result }\end{array}$ & \multicolumn{2}{l}{ Checklist result } \\
\cline { 2 - 3 } & Never & Sometimes \\
\hline $\begin{array}{l}\text { None } \\
(<1 \% \text { cycle })\end{array}$ & 17 & 16 \\
$\begin{array}{l}\text { Some } \\
(>1 \% \text { cycle })\end{array}$ & 1 & 17 \\
\hline
\end{tabular}

Perfect agreement (main diagonal) $=34$ jobs, 67 percent of jobs in sample

Checklist rating $>$ Expert rating $=16$ jobs, 31 percent of jobs in sample

Checklist rating $<$ Expert rating $=1$ jobs, 2 percent of jobs in sample

Table 9

Checklist vs. expert analysis of postural stresses associated with twisting or lateral bending of the trunk $\left(>20^{\circ}\right)$.

\begin{tabular}{llll}
\hline Experts & \multicolumn{2}{l}{ Checklist result } \\
\cline { 2 - 4 } results & Never & Sometimes & $>1 / 3$ cycle \\
\hline $\begin{array}{l}\text { None } \\
\quad(<1 \% \text { cycle })\end{array}$ & 3 & 16 & 5 \\
Some & & & \\
$\quad(1-33 \%$ cycle $)$ & 5 & 15 & 6 \\
$>33 \%$ cycle & 0 & 1 & 0 \\
\hline
\end{tabular}

Perfect agreement (main diagonal) $=18$ jobs, 35 percent of jobs in sample

Checklist rating $>$ Expert rating $=27$ jobs, 53 percent of jobs in sample

Checklist rating $<$ Expert rating $=6$ jobs, 12 percent of jobs in sample 
Table 10

Checklist vs. expert analysis of postural stresses associated with mild neck flexion $\left(20^{\circ}-45^{\circ}\right)$.

\begin{tabular}{lll}
\hline Expert & \multicolumn{2}{l}{ Checklist result } \\
\cline { 2 - 3 } result & $<1 / 3$ cycle & $>1 / 3$ cycle \\
\hline Some & & \\
$\quad(1-33 \%$ cycle $)$ & 8 & 7 \\
$>33 \%$ cycle & 9 & 0 \\
\hline
\end{tabular}

Perfect agreement (main diagonal) $=8$ jobs, 33 percent of jobs in sample

Checklist rating $>$ Expert rating $=7$ jobs, 29 percent of jobs in sample

Checklist rating $<$ Lxpert rating $=9$ jobs, 38 percent of jobs in sample

operating industrial trucks and (2) repacking bulk parts into individual containers.

\section{Checklist responses us. "expert" findings}

The results of the two-way comparisons between the checklist and expert results are presented in tables 7 through 13 . Table 14 summarizes these comparisons listing the checklist item being compared, the number of jobs used in the comparison and the number and percent of jobs where:

(1) the two methods were in agreement,

(2) the checklist overestimated the risk factor exposure compared to the expert analysis,

\section{Table 11}

Checklist vs. expert analysis of postural stresses associated with severe neck flexion $\left(>45^{\circ}\right)$.

\begin{tabular}{llll}
\hline $\begin{array}{l}\text { Experts } \\
\text { results }\end{array}$ & \multicolumn{2}{l}{ Checklist result } \\
\cline { 2 - 4 } & Never & Sometimes & $>1 / 3$ cycle \\
\hline $\begin{array}{l}\text { None } \\
\quad(<1 \% \text { cycle })\end{array}$ & 14 & 6 & 2 \\
Some & & & \\
$\quad(1-33 \%$ cycle $)$ & 1 & 1 & 0 \\
$>33 \%$ cycle & 0 & 0 & 0
\end{tabular}

Perfect agreement (main diagonal) $=15$ jobs, 63 percent of jobs in sample

Checklist rating $>$ Expert rating $=8$ jobs, 33 percent of jobs in sample

Checklist rating $<$ Expert rating $=1$ jobs, 4 perecnt of jobs in sample
Table 12

Checklist vs, expert andysis of postural stresses associated with neck extension $\left(>20^{\circ}\right)$.

\begin{tabular}{llll}
\hline $\begin{array}{l}\text { Experts } \\
\text { results }\end{array}$ & \multicolumn{3}{l}{ Checklist result } \\
\cline { 4 - 4 } & Never & Sometimes & $>1 / 3$ cycle \\
\hline $\begin{array}{l}\text { None } \\
(<1 \% \text { cycle })\end{array}$ & 18 & 2 & 1 \\
$\begin{array}{l}\text { Some } \\
(1-33 \% \text { cycle })\end{array}$ & 3 & 0 & 0 \\
$>33 \%$ cycle & 0 & 0 & 0
\end{tabular}

Perfect agreement (main diagonal) $=18$ jobs, 75 percent of jobs in sample

Checklist rating $>$ Lxpert rating $=3$ jobs, 12 percent of jobs in sample

Checklist rating $<$ Expert rating $=3$ jobs, 12 percent of jobs in sample

(3) the checklist underestimated the risk factor exposure compared to the expert analysis.

(4) the checklist overestimated or agreed with the expert results (our measure of sensitivity).

As can be seen from the right most column in Table 14, the checklist functioned as a sensitive screening tool for all of the postures except mild neck flexion (table 10) and twisted or laterally bent neck (table 13). Another problem evident from table 14 is that for mild trunk flexion (table 7) and trunk twisted or laterally bent (table 9) the checklist overestimated the exposure to these

Table 13

Checklist vs. expert analysis of postural stresses associated with twisting or lateral bending of the neck $\left(>20^{\circ}\right)$.

\begin{tabular}{llll}
\hline $\begin{array}{l}\text { Experts } \\
\text { results }\end{array}$ & Checklist result & \\
\cline { 2 - 3 } & Never & Sometimes & $>1 / 3$ cycle \\
\hline $\begin{array}{l}\text { None } \\
(<1 \% \text { cycle })\end{array}$ & 1 & 2 & 0 \\
Some & & & \\
$(1-33 \%$ cycle $)$ & 6 & 7 & 3 \\
$>33 \%$ cycle & 1 & 1 & 3 \\
\hline
\end{tabular}

Perfect agreement (main diagonal) $=11$ jobs, 46 percent of jobs in sample

Checklist rating $>$ Expert rating $=5$ jobs, 21 percent of jobs in sample

Checklist rating $<$ Expert rating $=8$ jobs, 33 percent of jobs in sample 
postures on 49 percent or more of the jobs. See the discussion section for an interpretation of these findings.

\section{Discussion}

\section{Survey of posture stresses}

This sub-section summarizes the awkward postures observed in this study by jobs and plants where they were prevalent. Awkward postures of the lower extremity were prevalent on about 25 percent of the surveyed jobs. Prolonged standing was required of machine operators in the pressed metal plant and the warehouses. Standing use of a foot pedal was observed among industrial truck drivers and machine operators in the warehouses. Squatting and kneeling occurred while handling parts from the bottom of pallets and bins placed on the floor in the warehouses and engine plant.

Awkward trunk postures were observed on over 70 percent of the jobs. Prolonged sitting was associated with industrial truck drivers and workers assembling and packaging parts kits in the warehouses. Mild flexion was used while reaching to load and unload machines and while reaching for parts at the far side of pallets and bins in all plants. Severe flexion resulted from working at the lower levels of pallets and bins and from long horizontal reaches (e.g., across large pallets and bins and across obstructions such as machine guards) in the engine plant and rack system frame members in the warehouses. Twisting or lateral bending stemmed from situations where parts, tools or machine controls were located beside or behind the worker.

Awkward neck postures were reported in all plants. Mild and severe flexion resulted from low, close workstations in the warehouses and engine plant. Extension was observed among industrial truck drivers who looked up while getting or setting loads. Twisting or lateral bending occurred when part supplies, tools or machine controls were located to the side or behind the worker.

Since the checklist used to evaluate these jobs was intended as a screening tool only, jobs rated as hazardous were expected to have follow-up evaluations using more sophisticated procedures (e.g., slow-motion analysis of videotapes, measurement of postures etc.). These evaluations would weed out false positives and relate postural stresses to specific job elements providing insights for redesign.

\section{Lack of agreement between checklist and "expert" results}

\section{Experimental protocol}

The protocol used in this study introduced measurement error that may have contributed to the lack of agreement between the checklist and the expert findings. Policy established at the outset of the study to assure independence of the checklist and expert analyses mandated that data collection for these activities could not be performed simultaneously; and in most cases the

\section{Table 14}

Summary of the comparisons.

\begin{tabular}{|c|c|c|c|c|c|}
\hline \multirow{2}{*}{$\begin{array}{l}\text { Checklist } \\
\text { item }\end{array}$} & \multirow{2}{*}{$\begin{array}{l}\text { Number } \\
\text { of jobs }\end{array}$} & \multirow{2}{*}{$\begin{array}{l}\text { Agree } \\
\text { Number } \\
\text { (percent) }\end{array}$} & \multirow{2}{*}{$\begin{array}{l}\text { Overestimate } \\
\begin{array}{l}\text { Number } \\
\text { (percent) }\end{array}\end{array}$} & \multirow{2}{*}{$\begin{array}{l}\text { Underestimate } \\
\text { Number } \\
\text { (percent) }\end{array}$} & \multirow{2}{*}{$\begin{array}{l}\text { Sensitive } \\
\text { percent }\end{array}$} \\
\hline & & & & & \\
\hline Trunk flexion & 51 & $24(47)$ & $25(49)$ & $2(4)$ & 96 \\
\hline Trunk sev flexion & 51 & $34(67)$ & $16(31)$ & $1(2)$ & 98 \\
\hline Trunk twist bent & 51 & $18(35)$ & $27(53)$ & $6(12)$ & 88 \\
\hline Neck flexion & 24 & $8(33)$ & $7(29)$ & $9(38)$ & 62 \\
\hline Neck sev flexion & 24 & $15(63)$ & $8(33)$ & 1 (4) & 96 \\
\hline Neck extension & 24 & $18(75)$ & $3(12)$ & $3(12)$ & 88 \\
\hline Neck twist bent & 24 & $11(46)$ & $5(21)$ & $8(33)$ & 67 \\
\hline
\end{tabular}


interval between data collection for the checklist and data collection for the expert analyses was several months. During this period some workers were reassigned; and there were many instances where different workers were observed for the checklist and expert analyses. The resulting differences in worker anthropometry and individual work methods could have contributed to poor correlation on work-method-sensitive measures such as trunk and neck postures. (The significance of an individual's work methods on the nature and magnitudc of measured ergonomic stresses has been documented in previous studies (Aaras et al., 1988; Hammarskjold et al., 1989; Stctson et al., 1991)). Furthermore, in a small number of warehouse jobs, there were minor differences in the size, shape, weight and/or packaging of parts considered for the checklist and expert analyses. These differences may have changed the work method, contributing to poor correlations in the trunk and neck posture comparisons. While the lack of consistency in work methods and/or handled parts would not systematically bias the results of either the checklist or expert analyses, it could increase the "noise" or lack of agreement between the two systems in a job-by-job comparison of findings.

Differences in the results of multiple ergonomic analyses which are caused by changes in workers and/or work methods are difficult to explain. In order to facilitate comparisons among different job analysis techniques in situations where workers and/or work methods change, it is essential that worker characteristics (e.g., body size, dominant hand etc.) and work methods be meticulously documented at the time of data collection. This documentation can prove to be invaluable in understanding changes in the apparent level of ergonomic stress when the same job is analyzed at different points in time or by different methods. See Keyserling et al. (1991) for additional information on ergonomic job analysis and documentation of work methods.

Another explanation for the lack of consistency between the checklist and expert cvaluations of neck and trunk postures is that the checklist was completed during direct observation of the job while the expert analyses were completed from videotape. There is a tradeoff between the two methods. Doing the analysis by direct observation allows the analyst to move around for the best view, to use three-dimensional cues and to talk to the worker about the postures used. The advantage of the videotape analysis is that the tape can be played in slow and stop motion, allowing time to study and measure the postures. Also, the videotape allows use of the computer to quantify the time spent in each posture, while this was estimated by checklist users.

Lack of agreement may have also resulted from differences in the expert and checklist methods. Due to limitations imposed by software and hardware, the expert could choose one and only one of the following postures at a given time: extension, neutral, mild flexion, severe flexion or twisted/laterally bent. Therefore, when a worker used two postures simultaneously, mild flexion and twisting/lateral bending for example, only the more stressful one of the two was recorded in the expert analysis. Thus, the expert analysis under-reported awkward postures that were simultancous. In contrast, the checklist recorded the duration of each posture separately. Because of this capability, the checklist produced higher percentages than the expert analysis for any single category of awkward postures. Resource limitations and protocol did not permit a detailed analysis of this effect.

\section{Long-cycle and non-repetitive jobs}

Variability between the checklist and expert results was also noted for jobs with long cycle times and for jobs that were not repetitive. An example of a long cycle time job was transferring parts between a pallet and a production line. The changing work height on the pallet required that the analysts consider the postures used for the entire pallet and not just at the moment of observations. Since limited time was available to complete the analysis, actual observations may not have covered the full range of postures used. Differences in the portion of the pallet observed could lead to poor agreement in the comparison of results.

Non-repetitive jobs included repair operations in the engine and pressed metal plants. Non-repetitive jobs in the warchouses included picking and packing activities where a wide variety of parts were handled. These jobs were especially 
frustrating to the analysts because the actions and postures were often different for each part handled. The lack of repetition in these jobs made determination of the postures and their duration difficult because many postures were seen only once, reducing the accuracy of both the expert and checklist results and leading to increased variability in their comparison. To better analyze non-repetitive jobs a different approach such as work sampling might be helpful (Niebel, 1988). We are currently exploring alternative methods for the analysis of non-repetitive jobs.

\section{Inter-analyst differences}

Another source of variability was the difference among analysts. A controlled study to evaluate the effects of different analysts studying the same job was not possible due to limited resources. The inter-analyst variability might be reduced through training. The training would involve using the checklist to analyze videotapes of several jobs for which postural exposure was known. Comparison of the checklist results with the "standard" results would identify analystspecific problems in recognizing postures or estimating durations. These problems could then be addressed.

\section{Sources contributing to checklist overestimation of awkward postures}

Sensitivity was important to minimize the number of "problem" jobs classified as "acceptable" (false negatives). To increase the sensitivity, the analysts who completed the checklists were instructed to choose the longer duration category or the more severe posture category (e.g., severe trunk flexion vs. mild trunk flexion) in borderline cases. These instructions would lead to some overestimation.

\section{Sources contributing to checklist underestimation of awkward postures}

As mentioned in the results section, underestimation of the stress associated with mild flexion and twisting or lateral bending of the neck occurred for about one-third of the jobs in the comparison. This underestimation may have been influenced by the following factors. First, in the analyst training, neck posture was emphasized less than trunk posture and ergonomic risk factors associated with upper extremity cumulative trauma disorders. This training bias may have resulted in less awareness and therefore underreporting of neck postures. Second, awkward neck posture such as mild flexion was very common according to informal feedback from the analysts. Because mild neck flexion was both common and not percieved as a serious ergonomic problem, the checklist users may have been unresponsive to this question.

\section{User acceptance}

Although the acceptability and ease-of-use of the checklist were never formally evaluated, several interviews were held with checklist users to elicit comments and suggestions for change. These interviews revealed that, in general, the checklist was well accepted. New users of the checklist found it to be a useful tool for learning specific postural risk factors. As users gained experience performing ergonomic job evaluations, the checklist served as a reminder or prompt to assure that some of the more subtle risk factors were not overlooked. Some users reported problems in classifying postures into neutral vs. non-neutral categories (due to the inability to directly measure joint angles) and in estimating the duration of non-neutral postures. Many users were frustrated by the inability of the checklist to associate the presence of risk factors ("checks" and "stars" on the form) with specific work activities. These users suggested that the checklist be modified to allow them to make supplemental notes in order to identify the work activities responsible for postural risk factors. This is another argument in favor of documenting worker characteristics and work methods at the time of data collection. This documentation would facilitate the checklist's use as a diagnostic aid in determining specific causes of ergonomic stress.

Although the "zero", "check", "star" system used for rating stresses is not a universally recognized system of ordinal ranking, checklist users reported no problem in learning or applying this system. However, alternate ranking systems such as "green", "yellow", "red" or " 1 ", " 2 ", " 3 " may be more intuitive, particularly for users who do not participate in a one-week training program. 


\section{Summary}

A one-page checklist for evaluating ergonomic risk factors associated with awkward postures was developed and evaluated as part of a joint unionmanagement ergonomics intervention program. This checklist was designed to be used by persons with limited ergonomic training as a rapid screening tool for identifying jobs with exposures to awkward postures. The checklist was used to assess postural risk factors on 335 jobs in four plants and was found to be an effective instrument for identifying potentially harmful exposures.

\section{Acknowledgements and disclaimer}

The authors thank Ms. Juliann Leonard, Mr. Andrew Bigelow, and Ms. Lisa Murphy for their assistance in the collection and analysis of data. The authors also thank the Ergonomic Coordinators and Ergonomic Monitors at the participating plant sites for facilitation of collection of in-plant data.

This project was supported by joint funds from the UAW/GM National Joint Committee on Health and Safety, which does not necessarily support or endorse the findings herein and which are solely the responsibility of the authors.

\section{Appendix}

Job Number

\section{ERGONOMIC RISK FACTOR CHECKLIST FOR AWKWARD POSTURE OF THE LEGS, TRUNK AND NECK}

\section{General Body Posture / Legs}

1. Standing stationary (no walking or leaning)

2. Using a foot pedal while standing

3. Lying on back or side

4. Knecling

5 . Knees bent or squatting

6. Sitting with back support

7. Sitting without back support

\section{Trunk Posture}

8. Mild forward bending $\left(>20^{\circ}\right)$

9. Severe forward bending $\left(>45^{\circ}\right)$

10. Backward bending $\left(>20^{\circ}\right)$

11. Twisting or lateral bending $\left(>20^{\circ}\right)$

\section{Neck Posture}

12. Mild forward bending $\left(>20^{\circ}\right)$

13. Severe forward bending $\left(>45^{\circ}\right)$

14. Backward bending ( $\left.>20^{\circ}\right)$

15. Twisting or lateral bending $\left(>20^{\circ}\right)$

Total Score $=\frac{}{\left(\text { No. of }{ }^{*} \text { 's }\right)} \cdot \frac{}{\text { (No. of } \boldsymbol{~} \text { 's })}$

\begin{tabular}{|c|c|c|}
\hline never & sometimes & $>1 / 3$ cycle \\
\hline o & 0 & 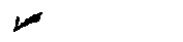 \\
\hline o & $\nu$ & $*$ \\
\hline o & $r$ & $*$ \\
\hline o & $\nu$ & $*$ \\
\hline 0 & 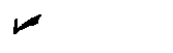 & $*$ \\
\hline never & $<1 / 3$ day & $>1 / 3$ day \\
\hline 0 & 0 & $\infty$ \\
\hline 0 & 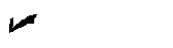 & $*$ \\
\hline never & sometimes & $>1 / 3$ cycle \\
\hline 0 & $\nu$ & $*$ \\
\hline 0 & $*$ & $*$ \\
\hline 0 & $\omega$ & $*$ \\
\hline 0 & $\nu$ & * \\
\hline
\end{tabular}

$\begin{array}{lll}0 & 0 & * \\ 0 & - & * \\ 0 & - & *\end{array}$

\section{Comments:}




\section{SUPPLEMENTAL NOTES FOR POSTURE CHECK LIST}

\section{Question}

1. Standing stationary (no walking or leaning)

Standing - The entire weight of the body is supported by the worker's legs.

Stationary - The worker remains in a standing posture without moving the lower extremities.

2. Using a foot pedal while standing

The weight of the body is supported by one foot while the other foot operates a pedal.

4. Knecling

One or two knees touch the ground.

5. Knees bent or squatting

The included angle between the thigh and the calf is less than $150^{\circ}$.

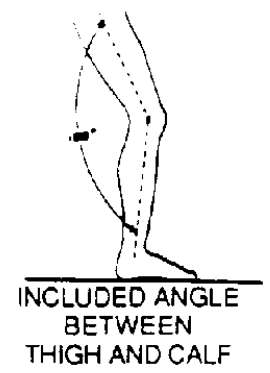

Trunk Posture

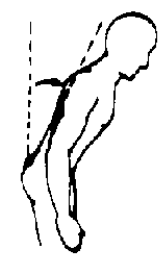

FORWARD BENDING mild is $20^{\circ}-45^{\circ}$ from vertical

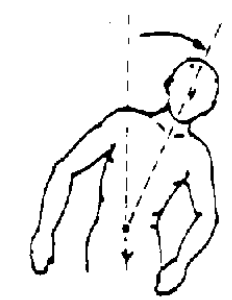

LATERAL BENDING

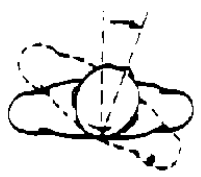

TWISTING

Neck Posture

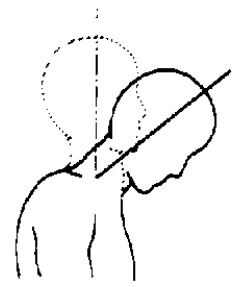

\section{References}

Aaras, A., Westgaard, R.H. and Stranden, E., 1988. Postural angles as an indicator of postural load and muscular injury in occupational work situations. Ergonomics, 31(6): 915933.

Aguayo, A.J., 1975. Neuropathy due to compression and entrapment. In: P.J. Dyck, P.K. Thomas and P.K. Lambert (Eds.), Peripheral Neuropathy. W.B. Saunders Company, Philadelphia, pp. 688-713.
Andersson, G.B.J., 1981. Epidemiologic aspects on low-back pain in industry. Spine, 6(1): 53-60.

Andersson, G.B.J., Ortengren, R. and Herberts, P., 1977. Quantitative electromyographic studies of back muscle activity related to posture and loading. Orthopedic Clinics of North America, 8(1): 85-96.

Andersson, B.J.G., Ortengren, R., Nachemson, A. and Elfstrom, G., 1974a. Lumbar disc pressure and myoelecrtic back muscle activity during sitting $I$. Studies on an experimental chair. Scandinavian Journal of Rehabilitation Medicine, 6(3): 104-114. 
Andersson, B.J.G., Ortengren, R., Nachemson, A. and Elfstrom, G., 1974b. Lumbar disc pressure and myoelectric back muscle activity during sitting IV. Studies on a car driver's seat. Scandinavian Journal of Rehabilitation Medicine, 6(3): 128-133.

Aricl, B.G., 1974. Biomechanical analysis of the knee joint during deep knee bends with a heavy load. In: R.C. Nelson and C.A. Morehouse (Eds.), Biomechanics IV. University Park Press, Baltimore, MD, pp. 44-52.

Astrand, P.-O. and Rodahl, K., 1986. Textbook of work physiology. McGraw-Hill Book Co., New York.

Atha, J., 1984. Current techniques for measuring motion. Applied Ergonomics, 15(4): 245-257.

Boussenna, M., Corlett, E.N. and Pheasant, S.T., 1982. The relationship between discomfort and postural loading at the joints. Ergonomics, 25(4): 315-322.

Buckle, P.W., Stubbs, D.A. and Baty, D., 1986. Musculoskeletal disorders (and discomfort) and associated work factors. In: E.N. Corlett, J. Wilson and I. Manenica (Eds.), The Ergonomics of Working Posture: Models, Methods and Cases. Taylor and Francis, London, pp. 19-30.

Chaffin, D.B., 1973. Localized muscle fatigue - Definition and measurement. Journal of Occupational Medicine, 15(4): $346-354$.

Chaffin, D.B. and Andersson, G.B.J., 1984. Occupational Biomechanics. John Wiley \& Sons, New York. Coffman, J.D., 1975. Diseases of the peripheral veins. In: P.B. Beeson and W. McDermott (Eds.), Textbook of Medicine Vol. II, 14th edition. W.B. Saunders Co., Philadelphia, pp. 1083-1084.

Corlett, E.N., Madeley, S.J. and Manenica, I., 1979. Posture targetting: A technique for recording working postures. Ergonomics, 22(3): 357-366.

Corlett, E.N. and Bishop, R.P., 1978. The ergonomics of spotwelders. Applied Ergonomics, 9(1): 23-32.

Corlett, E.N. and Bishop, R.P., 1976. A technique for assessing postural discomfort. Ergonomics, 19(2): 175-182.

Deverell, W.F. and Ferguson, J.H., 1968. An unusual case of sciatic nerve paralysis. The Journal of the American Medical Association, 205(10): 109-110.

Feldman, R.G., Goldman, R. and Keyserling, W.M., 1983. Peripheral nerve entrapment syndromes and ergonomic factors. American Journal of Industrial Medicine, 4(5): 661-681.

Gibbons, J.D., 1971. Non-Parametric Statistical Inference. McGraw-Hill Book Co., New York, pp. 263-267.

Grandjean, E., Hunting, W., Maeda, K. and Laubli, Th., 1983. Constrained postures at office workstations. In: T.O. Kvalseth (Ed.), Ergonomics of Workstation Design. Butterworths, London, pp. 19-27.

Hammarskjold, E., Ekholm, J. and Harms-Ringdahl, K., 1989. Reproducibility of work movements with carpenters' hand tools. Ergonomics, 32(8): 1005-1018.

Harms-Ringdahl, K., Ekholm, J., Schuldt, K., Nemeth, G. and Arborelius, U.P., 1986a. Load moments and myoelectric activity when the cervical spine is held in full flexion and extension. Ergonomics, 29(12): 1539-1552.

Harms-Ringdahl, K. and Ekholm, J., 1986b. Intensity and character of pain and muscular activity levels elicited by maintained extreme flexion position of the lower-cervicalupper-thoracic spine. Scandinavian Journal of Rehabilitation Medicine, 18(3): 117-126.

Hunting, W., Grandjean, E. and Maeda, K., 1980. Constrained postures in accounting machine operators. Applied Ergonomics, 11(3): 145-149.

Joubert, M.J., 1972. Tarsal tunnel syndrome. South African Medical Journal, 46(17): 507-508.

Karhu, O., Kansi, P. and Kuorinka, I., 1977. Correcting working postures in industry: A practical method for analysis. Applied Ergonomics, 8(4): 199-201.

Keyserling, W.M., 1986. Postural analysis of the trunk and shoulders in simulated real time. Ergonomics, 29(4): 569583.

Keyserling, W.M., 1990. Computer-aided posture analysis of the trunk, neck, shoulders and lower extremities. In: W. Karwowski, A.M. Genaidy and S.S. Asfour (Eds.), Computer-Aided Ergonomics. Taylor \& Francis, London, pp. 261-272.

Keyserling, W.M., Armstrong, T.J. and Punnett, L., 1991. Ergonomic job analysis: A structured approach for identifying risk factors associated with overexertion injuries and disorders. Applied Occur. Environ. Hyg., 6(5): 353-363.

Keyserling, W.M., Bigelow, A.B., Brouwer, M.L. and Murphy, L.A., 1990. Ergonomic job analysis: Methods to identify, evaluate, and control exposures to risk factors in the workplace. In: B. Das (Ed), Advances in Industrial Ergonomics and Safety II. Taylor \& Francis, London, pp. 963-970.

Keyserling, W.M., Stetson, D., Silverstein, B.S. and Brouwer, M.L., in press. A checklist for evaluating upper extremity cumulative trauma disorders. Ergonomics.

Kilbom, A. and Persson, J., 1987. Work technique and its consequences for musculoskeletal disorders. Ergonomics, 30(2): 273-279.

Kilbom, A., Persson, J. and Jonsson. B.G., 1986a. Disorders of the cervicobrachial region among female workers in the electronics industry. International Journal of Industrial Ergonomics, 1(1): 37-47.

Kilbom, A., Persson, J. and Jonsson, B., 1986b. Risk factors for work-related disorders of the neck and shoulder - with special emphasis on working postures and movements. In: E.N. Corlett, J. Wilson and I. Manenica (Eds.), The Ergonomics of Working Posture: Models, Methods and Cases. Taylor \& Francis, London, pp. 44-53.

Koller, R.L. and Blank, N.K., 1980. Strawberry pickers' palsy. Archives of Neurology, 37(5): 320.

Maeda, K., Okazaki, F., Suenaga, T., Sakurai, T. and Takamatsu, M., 1980. Low back pain related to bowing posture of greenhouse farmers. Journal of Human Ergology, 9(2): 117-123.

Magnusson, M., Ortengren, R., Andersson, G.B.J., Petersen, I. and Sabel, B, 1987. An ergonomic study of work methods and physical disorders among professional butchers. Applied Ergonomics, 18(1): 43-50.

Magora, A., 1972. Investigation of the relation between low back pain and occupation 3 . Physical requirements: Sitting, standing and weight lifting. Industrial Medicine, 41(12): 5-9. 
Nachemson, A., 1966. The load on lumbar disks in different positions of the body. Clinical Orthopaedics and Related Research, 45: 107-122.

Niebel, B.W., 1988. Motion and Time Study 8th Edition. Irwin, Homewood, IL pp. 575-610.

Occupational Safety and Health Administration (OSHA), 1990. Ergonomics Program Management Guidelines for Meatpacking Plants. Publication No. OSHA-3121, U.S. Department of Labor, Washington, DC.

Paluch, R., 1989. Physical load of musculoskeletal system and sick leaves of the metallurgic workers. In: A. Mital (Ed.), Advances in Industrial Ergonomics and Safety I. Taylor and Francis, London, pp. 747-755.

Priel, V.Z., 1974. A numerical definition of posture. Human Factors, 16(6): 576-584.

Punnett, L., Fine, L.J., Keyserling, W.M., Herrin, G.D. and Chaffin, D.B., 1991. Back disorders and nonneutral trunk postures of automobile assembly workers. Scandinavian Journal of Work, Environment and Health, 17: 337-346.

Ryan, G.A., 1989. The prevalence of musculo-skeletal symptoms in supermarket workers. Ergonomics, 32(4): 359-371.

Sandhu, H.S. and Sandhey, B.S., 1976. Occupational compression of the common peroneal nerve at the neck of the fibula. The Australian and New Zealand Journal of Surgery, 46(2): 160-163.

Sato, M. and Tanaka, S., 1973. Postural effect on the relation between oxygen consumption and heart rate. Journal of Human Ergology, 2(1): 21-30.

Spaans, F., 1970. Occupational nerve lesions. In: P.J. Vinken and G.W. Bruyn (Eds.), Handbook of Clinical Neurology, Vol. 7: Diseases of Nerves, Part 1. American Elsevier Pub. Co., Inc., New York, pp. 326-343.

Stalhammar, H.R., Leskinen, T.P.J., Kuorinka, I.A.A., Gautreau, M.H.J. and Troup, J.D.G., 1986. Postural, epidemiological and biomechanical analysis of luggage han- dling in an aircraft luggage compartment. Applied Ergonomics, 17(3): 177-183.

Stetson, D.S., Keyserling, W.M., Silverstein, B.A. and Leonard, J.A., 1991.

Observational analysis of the hand and wrist: A pilot study. Appl. Occup. Environ. Hyg., 6(11): 927-937.

Tanaka, S., Smith, A.B., Halperin, W. and Jensen, R., 1982. Carpet-layer's knee. New England Journal of Medicine, 307(20): 1276-1277.

Tola, S., Riihimaki, H., Videman, T., Viikari-Juntura, E. and Hanninen, K., 1988. Neck and shoulder symptoms among men in machine operating, dynamic physical work and sedentary work. Scandinavian Journal of Work, Environment \& Health, 14(5): 299-305.

Torner, M., Blide, G., Eriksson, H., Kadefors, R., Karlsson, R. and Petersen, I., 1988. Musculo-skeletal symptoms as related to working conditions among Swedish professional fishermen. Applied Ergonomics, 19(3): 191-201.

Travell, J., 1967. Mechanical headache. Headache, 7(1): 23-29.

Van Wely, P., 1970. Design and disease. Applied Ergonomics, 1(5): 262-269.

Viikari-Juntura, E., 1983. Neck and upper limb disorders among slaughterhouse workers. An epidemiologic and clinical study. Scandinavian Journal of Work, Environment \& Health, 9(3): 283-290.

Westgaard, R.H. and Aaras, A., 1984. Postural muscle strain as a causal factor in the development of musculo-skeletal illnesses. Applied Ergonomics, 15(3): 162-174.

Winkel, J., Jorgensen, K. and Noddeland, H., 1988. Significance of ambient temperature for foot swelling and oedema-preventing effect of modest leg activity while seated. In: A.S. Adams, R.R. Hall, B.J. McPhee and M.S. Oxenburgh (Eds.), Ergonomics International 88. Taylor \& Francis, London, pp. 140-142. 